Article

\title{
Contamination Characteristics and Assessment of Manganese, Zinc, Chrome, Lead, Copper and Nickel in Bus Station Dusts of Xifeng, Northwest China
}

\author{
Yongfu Wu ${ }^{1,2, *}$, Xinwei Lu ${ }^{1, *}$, Sukai Zhuang ${ }^{1}$, Xiufeng Han ${ }^{1}$ and Yan Zhou ${ }^{1}$ \\ School of Tourism and Environmental, Shaanxi Normal University, Xi'an 710062, China \\ Agriculture and Forestry Science and Technology College, Longdong University, Qingyang 745000, China \\ * Correspondence: yongfu2006@126.com (Y.W.); luxinwei@snnu.edu.cn (X.L.); \\ Tel.: +8629 85310525; fax: +862985303883.
}

\begin{abstract}
The objective of this study was to investigate the concentration and spatial distribution patterns of six potentially toxic heavy metal elements $(\mathrm{Mn}, \mathrm{Zn}, \mathrm{Cr}, \mathrm{Pb}, \mathrm{Cu}$ and $\mathrm{Ni}$ ) in bus station dusts in the Xifeng district of Gansu province, NW China. The contents were analyzed for $\mathrm{Mn}, \mathrm{Zn}, \mathrm{Cr}, \mathrm{Pb}$, $\mathrm{Cu}$ and $\mathrm{Ni}$ by using S8 TIGER Brochures wavelength dispersive X-ray fluorescence spectrometry. Geoaccumulation index $\left(\mathrm{I}_{\text {geo }}\right)$, enrichment factor $(\mathrm{EF})$, pollution index $(\mathrm{PI})$ and integrated pollution index(IPI) were calculated to evaluate the heavy metal contamination level of bus station dusts. The results indicate that, in comparison with the background values of local soil, bus station dusts in Xifeng have elevated metal concentrations as a whole. The concentrations of heavy metals investigated in this paper are compared with the reported data of other cities. The results show that the arithmetic means of $\mathrm{Mn}, \mathrm{Zn}, \mathrm{Cr}, \mathrm{Pb}, \mathrm{Cu}$ and $\mathrm{Ni}$ are $440.8,137.9,60.0,42.8,33.5$ and $19.8 \mathrm{mg} \mathrm{kg}^{-1}$ respectively. The mean values of $\mathrm{I}_{\text {geo }}$ reveal the order of $\mathrm{Ni}<\mathrm{Mn}<\mathrm{Cr}<\mathrm{Cu}<\mathrm{Zn}<\mathrm{Pb}$. The high $\mathrm{I}_{\text {geo }}$ and $\mathrm{EF}$ for $\mathrm{Cu}, \mathrm{Zn}$ and $\mathrm{Pb}$ in bus station dusts indicate that there is a considerable $\mathrm{Cu}, \mathrm{Zn}$ and $\mathrm{Pb}$ pollution, which mainly originate from traffic and industry activities. The $\mathrm{I}_{\text {geo }}$ and $\mathrm{EF}$ of $\mathrm{Ni}, \mathrm{Mn}$ and $\mathrm{Cr}$ are low and the assessment results indicate an absence of distinct $\mathrm{Ni}, \mathrm{Mn}$ and $\mathrm{Cr}$ pollution in bus station dusts. The assessment results of $\mathrm{PI}$ also support $\mathrm{Cu}, \mathrm{Zn}$ and $\mathrm{Pb}$ in bus station dusts presented middle pollution, and IPI indicates heavy metals of bus station dusts polluted seriously.
\end{abstract}

Keywords: heavy metal; contamination assessment; X-ray fluorescence; bus station dusts

1. Introduction

bus station dusts, particles deposited on a road, originates from the interaction of solid, liquid and gaseous materials produced from different sources (Banerjee ADK. 2003; Ferreira-Baptista and De Miguel 2005; Zhao et al. 2007; Shi et al. 2011; Lu et al. 2014a). Components and quantity of bus station dusts are environmental pollution indicators (Han et al. 2006; Al-Khashman 2007; Zheng et al. 2010). bus station dusts receives varying inputs of heavy metals from a variety of mobile or stationary sources (Ferreira-Baptista and De Miguel 2005; Ma and Singhirunnusorn 2012; Zhao and Li 2013), such as vehicular traffic, industrial plants, residential oil burning, waste incineration, construction and demolition activities and resuspension of surrounding contaminated soils (Wei and Yang 2010; Apeagyei et al. 2011; Duong and Lee 2011; Yuen et al. 2012; Rout et al. 2013; Zhu et al. 2013; Nazzal et al. 2014), and makes a significant contribution to the pollution in the urban environment, and is one of the most pervasive and important factors affecting human health (Han et al. 2006; Al-Khashman 2007; Zheng et al. 2010). Road dust plays an active role as a"sink and source"of pollutants due to enhanced levels of 
metals and other pollutants and frequent interactions of dust with the atmosphere and other mediums through resuspension and deposition of dust particles (Moreno et al. 2013). Therefore, road dust can contribute significantly to environmental pollution in urban areas and is considered an indicator of heavy metal contamination from atmospheric deposition (Zheng et al. 2010). Moreover, Heavy metals in street dust are highly concerning because of their toxicity and non-degradability, as well as threat to the environment and the public health (Banerjee 2003; Wei and Yang 2010). These particles can easily enter human body through inhalation, ingestion or dermal contact (Ahmed and Ishiga 2006; Wei and Yang 2010; Shi et al. 2011) and harm urban residents health by public transportation going out, especially children. Therefore, the study of bus station dusts is important for determining the origin, distribution and level of heavy metal in urban surface environments.

Many studies on surface dust have focused on trace metal elements concentration, distribution and source identification in the last decades (Li et al. 2001; Banerjee 2003; Sezgin et al. 2003; Ahmed and Ishiga 2006; Han et al. 2006, 2008; Wei and Yang 2010; Zheng et al. 2010; Duong and Lee 2011; Shi et al. 2011; Ma and Singhirunnusorn 2012; Chen et al. 2014; Wang and Liang 2014; Wang et al. 2015; Xu et al. 2015). Elevated levels of trace metal contents are ubiquitous in urban settings as a result of a wide range of human activities. while little information is available for bus stations of cities, which were most often appear.

Xifeng, one important oil production and refining industrial district in Northwest China, has experienced a rapid urbanization and industrialization in the last two decades. The rapid growth of industry, population and vehicle exerts a heavy pressure on its urban environment. The main objective of this initial study was to determine the concentration of heavy metals in bus station dusts samples collected from Xifeng district and to assess their contaminated level.

\section{Materials and methods}

\subsection{Study area}

Xifeng $\left(35^{\circ} 25^{\prime} 55^{\prime \prime}-35^{\circ} 51^{\prime} 11^{\prime \prime} \mathrm{N}, 107^{\circ} 27^{\prime} 42^{\prime \prime}-107^{\circ} 52^{\prime} 48^{\prime \prime} \mathrm{E}\right)$, the busiest district of Qingyang city in Northwestern China, is situated at the southern end of the city in Loess Plateau. The district spans over $996.35 \mathrm{~km}^{2}$ with the urban population of approximately 325.2 thousand in 2015 . It has a typical semi-arid temperate continental monsoon climate, with an annual average temperature of $9.6^{\circ} \mathrm{C}$, annual average precipitation of $465.7 \mathrm{~mm}$ and annual evaporation capacity of $1613.1 \mathrm{~mm}$, the annual sunlight is about $2500 \mathrm{~h}$. The local soil type is mainly sandy and yellow clay with a $\mathrm{pH}\left(\mathrm{H}_{2} \mathrm{O}\right) 8.56$. The prevailing wind direction is northwest. The urban area of Xifeng is approximately $600 \mathrm{~km}^{2}$, respectively. The number of motor vehicles driven in Xifeng in 2015 was approximately 150 thousand vehicles. Xifeng has abundant gas, coal, oil and other mineral resources. It is an important industrial base of China, oil exploitation, refining and transporting are the major industries of Xifeng. The texture analysis of the soil shows that it is loam soil, composed of clayey soil $14.12 \%-21.20 \%$, silty sand $36.60 \%-41.94 \%$ and fine sand $36.86 \%-49.28 \%$. The prevailing wind direction is from northwest to southeast.

\subsection{Sampling and analytical procedures}

Fifty-three bus station dusts sampling sites were selected in Xifeng district, including public parks, schools, heavy and low traffic density areas, commercial areas and residential districts(Fig.1). At every sampling site, about $500 \mathrm{~g}$ bus station dusts composite sample was collected by sweeping using polyethylene brush and tray from five to eight points of road/pavement edges during the dry season in 
April 2016. All collected bus station dusts samples were stored in the sealed polyethylene bags, labeled and then transported to the laboratory.

All the samples were air-dried in the laboratory for 2 weeks, and then sieved through a $2 \mathrm{~mm}$ mesh nylon sieve to remove large stones, crop and grass debris before halving. One half was stored, the other one was then ground-with agate mortar and pestle-carefully homogenized and sieved through $0.074 \mathrm{~mm}$ (200 mesh) were ground further in a grinding miller. After reduction by repeated quartering, the sample was analyzed as outlined below.

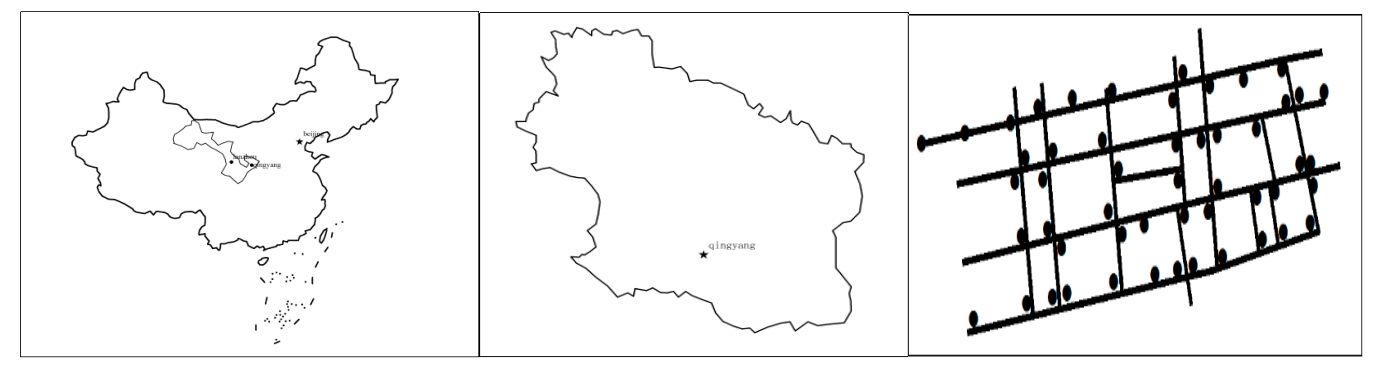

Fig. 1. The location of the study area in China.

All procedures of handling were carried out without contact with metals, to avoid potential cross-contamination of the samples. Weigh $5.0 \mathrm{~g}$ of milled bus station dusts sample and $2.0 \mathrm{~g}$ of boric acid and place in the mold, and press into a $32-\mathrm{mm}$ diameter small briquette under $31.5 \mathrm{t}$ pressure, and the briquettes were stored in a desiccator. Therefore, the concentrations of $\mathrm{Mn}, \mathrm{Zn}, \mathrm{Pb}, \mathrm{Cr}, \mathrm{Cu}$ and $\mathrm{Ni}$ in bus station dusts samples were directly measured by wavelength dispersive X-ray fluorescence spectrometry (S8 TIGER Brochures, XRF), the relative proportions of dust were determined according to methods (dos Anjos et al. 2000; Staloki et al. 2004; Huang and 1i, 2007; Lu et al. 2009a, 2009b). Meanwhile, a series of soil and rock standards were used to calibrate the application. These were the GSS- and GSDseries geochemical reference materials (Institute of Geophysical and Geochemical Prospecting, PR China). The analytical precision, measured as relative standard deviation, was routinely between $2 \%$ and $4 \%$, and never higher than $6 \%$. Accuracy of analyses was checked using standard and duplicate samples. The quality control gave good precision (S.D. $<4 \%$ ) for all samples.

\subsection{Contamination assessment methods}

A number of calculation methods have been put forward for quantifying the degree of metal enrichment or pollution in soils and dusts(Gonzalez-Macias et al. 2006; Gagneten et al. 2007; Gemici and Tarcan, 2007; Gonzalez-Macias et al. 2007; Hu et al. 2011; Han et al. 2014; Li et al. 2015). In the study, geoaccumulation index ( $\mathrm{I}_{\text {geo }}$ ), enrichment factor (EF), pollution index (PI) and integrated pollution index (IPI) were calculated to assess the heavy metal contamination level in the bus station dusts.

Igeo was originally used with bottom sediments in Ref. (Müller, 1969). It is computed by the following equation: $\mathrm{I}_{\mathrm{geo}}=\log _{2} \frac{\mathrm{C}_{\mathrm{x}}}{1.5 \mathrm{~B}_{\mathrm{x}}}$

where $\mathrm{Cx}$ is the measured concentration $\mathrm{f}$ the elem $\mathrm{nt} \mathrm{x}$ and $\mathrm{Bx}$ is the geochemical background value of 0 $\mathrm{e}$

the element. In the study, $\mathrm{Bx}$ is the background content of the element $\mathrm{x}$ in Chinese soil(CNEMC, 1990). The constant 1.5 is introduced to minimize the effect of possible variations in the background values which may be attributed to lithologic variations in the sediments. The following classifications is given for geoaccumulation index(Müller, 1969): unpolluted ( $\mathrm{I}_{\text {geo }}<0$ ), unpolluted to moderately polluted 
$\left(0 \leq \mathrm{I}_{\text {geo }}<1\right)$, moderately polluted $\left(1 \leq \mathrm{I}_{\text {geo }}<2\right)$, moderately to strongly polluted $\left(2 \leq \mathrm{I}_{\text {geo }}<3\right)$, strongly polluted $\left(3 \leq\right.$ Igeo $\left._{\text {go }}<4\right)$, strongly to extremely polluted $\left(4 \leq \mathrm{I}_{\text {geo }}<5\right)$, and extremely polluted ( geo $\left._{\text {ge }} \geq 5\right)$.

Enrichment factor (EF) of an element in the studied samples was based on the standardization of a measured element against a reference element. A reference element is often the one characterized by low occurrence variability, such as the most commonly used elements: $\mathrm{Al}, \mathrm{Fe}, \mathrm{K}, \mathrm{Si}$, Sr, Ti, etc. (Tasdemir and Kural 2005; Turner and Simmonds 2006; Hao et al. 2007; Kartal et al. 2006; Meza-Figueroa et al. 2007; Mandal and Sengupta 2003; Cao et al. 2011). The EF calculation is expressed below as

$$
\mathrm{EF}=\frac{\left[\mathrm{C}_{\mathrm{x}} / \mathrm{C}_{\text {ref }}\right]_{\text {Sample }}}{\left[\mathrm{C}_{\mathrm{x}} / \mathrm{C}_{\text {ref }}\right]_{\text {Background }}}
$$

where $\mathrm{C}_{\mathrm{x}}$ is the concentration of the element of interest and $\mathrm{C}_{\mathrm{ref}}$ is the concentration of reference element for normalization. In this study, $\mathrm{Al}$ was selected as the reference material. EF values less than 5.0 are not considered significant, because such small enrichments may arise from differences in the composition of local soil material and reference soil used in EF calculations( Kartal et al.2006).

However, there is no accepted pollution ranking system or categorization of degree of pollution on the enrichment ratio and/or factor methodology. Five contamination categories are recognized on the basis of the enrichment factor: states deficiency to minimal enrichment $(\mathrm{EF}<2)$, moderate enrichment $(2 \leq \mathrm{EF}<5)$, significant enrichment $(5 \leq \mathrm{EF}<20)$, very high enrichment $(20 \leq \mathrm{EF}<40)$ and extremely high enrichment（ $E F \geq 40 ）$ (Han et al. 2006; Kartal et al. 2006; Lu et al. 2010; 2014a and b ).

Pollution index and integrated pollution index are also commonly used to assess the environment quality( Chen et al. 2005). The PI was defined as the ratio of element concentration in the study to the background content of the corresponding element of Chinese soil(CNEMC, 1990). The pollution index obtained by the following equation: $\mathrm{PI}=\frac{\mathrm{C}_{\mathrm{x}}}{\mathrm{B}_{\mathrm{x}}}$

The PI of each element was calculated and classified as either $\leq 1=$ low pollution, $1<\mathrm{PI} \leq 3=$ middle pollution, or $>3=$ high.

The integrated pollution index (IPI) of the six heavy metals is obtained by the following equation:

$$
\mathrm{IPI}=\sqrt{\frac{P_{\text {mean }}^{2}+P^{2}{ }_{\text {max }}}{2}}
$$

where $\mathrm{P}_{\text {mean }}$ and $\mathrm{P}_{\max }$ are the mean value and max value of the pollution index (PI) of 6 kinds of metals. $\mathrm{IPI} \leq 1$ indicates that dusts are low pollution, $1<\mathrm{IPI} \leq 2$ illustrates that dusts are middle pollution, IPI $>2$ illustrates that dusts are high pollution (Chen et al. 2001).

\section{Results and discussion}

\subsection{Heavy metal concentration in bus station dusts}

The descriptive statistic results of heavy metal concentrations investigated in bus stations samples, as well as background values of Chinese soils(CNEMC, 1990), are listed in Table 1. Table 1 shows that the arithmetic means of $\mathrm{Mn}, \mathrm{Zn}, \mathrm{Cr}, \mathrm{Pb}, \mathrm{Cu}$ and $\mathrm{Ni}$ are 442.8, 144.2, 61.0, 44.9, 34.6 and $22.2 \mathrm{mg} \mathrm{kg}^{-1}$, respectively. The mean concentrations of $\mathrm{Cr}$ in dust samples collected from bus station of Xifeng is close to the background values of Chinese soil. Table 1 shows the concentrations of $\mathrm{Mn}$ and $\mathrm{Ni}$ in bus station dusts of Xifeng are lower than the background values of Chinese soils, and the concentrations of $\mathrm{Zn}, \mathrm{Pb}$ and $\mathrm{Cu}$ in bus station dusts of Xifeng are higher than the background values of Chinese soils. The 
geometric means of all studied metals are approximately equal to their arithmetic means, which are $440.8,137.9,60.0,42.8,33.5$ and $19.8 \mathrm{mg} \mathrm{kg}^{-1}$, respectively for $\mathrm{Mn}, \mathrm{Zn}, \mathrm{Cr}, \mathrm{Pb}, \mathrm{Cu}$ and $\mathrm{Ni}$. These are especially true for $\mathrm{Zn}, \mathrm{Pb}$ and $\mathrm{Cu}$, which are 2.36, 2.43 and 1.69 times the background values of Chinese soil, respectively.The maximums of $\mathrm{Mn}, \mathrm{Zn}, \mathrm{Cr}, \mathrm{Pb}, \mathrm{Cu}$ and $\mathrm{Ni}$ have been found in the sample from heavy traffic site, such as nursery schools, primary schools, secondary schools, housing estates and city center apartments blocks and bus stops, while their minimums were detected in dust sample from bus stations of the city edge, such as residential site with less traffic density. The source of $\mathrm{Ni}, \mathrm{Pb}$ and $\mathrm{Zn}$ in bus station dusts was indicated by research as tyre abrasion, the corrosion of metallic parts of cars, lubricants and industrial and incinerator emissions(Al-Khashman 2004; Arslan 2001; Jiries et al. 2001; $\mathrm{Lu}$ et al. 2010; 2014a and b). The values of the mean concentration of heavy metals in dust from bus stations of Xifeng divided by the corresponding background values of Chinese soil decrease in the order $\mathrm{Mn}>\mathrm{Zn}>\mathrm{Cr}>\mathrm{Pb}>\mathrm{Cu}>\mathrm{Ni}$. Small standard deviations and variation coefficients (SD/mean) were found for all heavy metals in bus stations dust, except for Ni. It may be concluded the sources of these heavy metals in bus station dusts of Xifeng mainly originated from anthropogenic activities (e.g. oil refining and coal combustion)and automotive emissions. Concentrations of $\mathrm{Mn}$ in all dust samples were found to be in the range of $354.6-549.4 \mathrm{mg} \mathrm{kg}^{-1}$ which are lower than Mn background value of Chinese soils (553 $\mathrm{mg} \mathrm{kg}^{-1}$ ), this shows $\mathrm{Mn}$ in bus station dusts mainly originated from natural source.

Table 1 Heavy metal concentrations $\left(\mathrm{mg} \mathrm{kg}^{-1}\right)$ in bus station dusts collected from Xifeng district

\begin{tabular}{|c|c|c|c|c|c|c|c|c|c|}
\hline Element & Minimum & Maximum & Mean & S.D. & GM & Median & Skewness & Kurtosis & Reference value (CNEMC, 1990) \\
\hline $\mathrm{Mn}$ & 354.6 & 549.4 & 442.8 & 41.7 & 440.8 & 444.5 & 0.1 & 0.6 & 553.0 \\
\hline $\mathrm{Zn}$ & 64.7 & 343.2 & 144.2 & 45.8 & 137.9 & 135.5 & 1.7 & 5.8 & 61.0 \\
\hline $\mathrm{Cr}$ & 36.7 & 95.2 & 61.0 & 11.0 & 60.0 & 61.8 & 0.5 & 1.4 & 61.8 \\
\hline $\mathrm{Pb}$ & 20.1 & 96.2 & 44.9 & 15.6 & 42.8 & 39.8 & 1.7 & 2.9 & 18.5 \\
\hline $\mathrm{Cu}$ & 17.8 & 58.8 & 34.6 & 8.7 & 33.5 & 34.2 & 0.3 & 0.0 & 20.5 \\
\hline $\mathrm{Ni}$ & 12.7 & 151.3 & 22.2 & 19.1 & 19.8 & 18.6 & 6.3 & 42.3 & 29.0 \\
\hline
\end{tabular}

Table 1 shows $\mathrm{Zn}, \mathrm{Pb}$ and $\mathrm{Ni}$ the skewness values of heavy metals are higher than unit which means all the elements skew towards the lower concentrations, as can also be confirmed by the fact that the median concentrations of these metals are lower than their mean concentrations, except for $\mathrm{Zn}, \mathrm{Mn}$ and Cr. So, the geometric and arithmetic means of all heavy metals investigated present more probable content data.

It is a common practice to compare mean concentrations of heavy metals in bus stations dusts in different urban environments (De Miguel et al 1997; Charlesworth 2003; Duzgoren-Aydin et al. 2006; Lu et al. 2009b; Li et al. 2012; Xu et al. 2015), although there are no universally accepted sampling and analytical procedures for geochemical studies of urban deposits. In table 2, concentrations of heavy metals measured in bus station dusts of Xifeng are compared with data reported for other cities streets dusts (Xu et al. 2004; Guo et al. 2005; Han et al. 2006; Gao et al. 2007; Shi et al. 2008; Lu et al. 2009a; Wei et al. 2009; Zhang and Wang 2009; Li et al. 2012; Shi et al. 2013; Han et al. 2014, 2016; Liu et al. 2014; Wang et al. 2014; Zhao et al. 2016).

The mean concentration of Mn in bus station dusts sampled in Xifeng (this work) is similar to those sampled in Inner Mongolia B., higher than those sampled in Xining, and lower than those sampled in Baoji, Baotou, Bayan Obo, China B., Hangzhou, Nanjing, Urumqi and Xi'an. The mean concentration table 2 of $\mathrm{Zn}$ in bus station dusts of Xifeng is low compared with several cites in the world except for Baotou, China B., Inner Mongolia B., Xining. The mean concentration of $\mathrm{Cr}$ in bus station dusts sampled 
in Xifeng is similar to those sampled in Changchun, higher than those sampled in China B., Hangzhou, Inner Mongolia B. and Urumqi, and lower than those sampled in Baoji, Baotou, Bayan Obo, Nanjing, Shanghai, Xi'an, Xianyang and Xining. The mean concentration of $\mathrm{Pb}$ for bus station dusts in Xifeng (this work) is lower than other compared cites except for China B. and Inner Mongolia B.. The Cu concentration in bus station dusts of Xifeng is similar to Bayan Obo, while lower than other cities except for Baotou, China B. and Inner Mongolia B.. On the other hand, the mean concentration of Ni in bus station dusts of Xifeng (this work) is similar to Baotou, Changchun, China B. and Xining, while lower than other cites except for Inner Mongolia B. (Table 2). In general, each city has its own characteristics combination of elemental compositions, and the observed similarities as well as variations may not reflect actual natural and anthropogenic diversities among the different urban settings. Therefore, there is an immediate need to establish a standard procedure to represent and analyze urban samples (Duzgoren-Aydin et al. 2006; Lu et al. 2009b; Li et al. 2012; Xu et al. 2015).

Table 2 A comparison of the heavy metal concentrations $\left(\mathrm{mg} \mathrm{kg}^{-1}\right)$ in street dusts of Xifeng and other selected cities

\begin{tabular}{|c|c|c|c|c|c|c|c|}
\hline District & $\mathrm{Mn}$ & $\mathrm{Zn}$ & $\mathrm{Cr}$ & $\mathrm{Pb}$ & $\mathrm{Cu}$ & $\mathrm{Ni}$ & Reference \\
\hline Baoji & 804.2 & 715.3 & 126.7 & 433.2 & 123.1 & 48.8 & Lu et al.2009a \\
\hline Baotou & 548.2 & 85.9 & 182.1 & 58.2 & 29.1 & 21.2 & Han et al.2014, 2016 \\
\hline Bayan Obo & 3407.3 & 299.3 & 141.2 & 183.9 & 36.3 & 31.2 & Wang et al.2014 \\
\hline China B. & 482.0 & 67.7 & 53.9 & 23.6 & 20.0 & 23.4 & Xu et al.2004 \\
\hline Changchun & - & 170.8 & 60.3 & 70.8 & 43.5 & 23.1 & Guo et al.2005 \\
\hline Guiyang & - & 243 & - & 79.5 & 66.1 & 38.9 & Li et al.2012 \\
\hline Hangzhou & 509.5 & 321.4 & 51.2 & 202.1 & 116.0 & 25.8 & Zhang and Wang, 2009 \\
\hline Inner & 434.3 & 47.5 & 35.7 & 13.5 & 12.7 & 16.6 & Xu et al.2004 \\
Mongolia B. & & & & & & & Gao et al.2007 \\
\hline Nanjing & 786.0 & 307.0 & 139.0 & 113.0 & 238.0 & 47.0 & Liu et al.2014 \\
\hline Shanghai & - & 733.8 & 159.3 & 294.9 & 196.8 & 83.9 & Shi et al.2008 \\
\hline Urumqi & 926.0 & 294.4 & 54.2 & 53.5 & 94.5 & 43.2 & Wei et al.2009 \\
\hline Xi'an & 687 & 421.4 & 167.2 & 230.5 & 94.9 & - & Shi et al.2006 2013 \\
\hline Xianyang & - & 375.3 & 135.6 & 77.3 & 132.1 & 69.5 & Zhao et al.2016 \\
\hline Xining & 409.1 & 108.6 & 573.0 & 52.7 & 40.6 & 22.6 & This work \\
\hline Xifeng & 441.3 & 144.8 & 60.7 & 45.1 & 34.5 & 22.3 & \\
\hline
\end{tabular}

- Not available.

3.2. Assessment results of the heavy metal contamination in bus station dusts

The calculated results of $\mathrm{I}_{\text {geo }}$ of heavy metals in Xifeng bus station dusts are presented in Fig. 1. The $\mathrm{I}_{\mathrm{geo}}$ of $\mathrm{Mn}$ ranges from -1.21 to -0.59 with a mean value of $-0.92,-0.49$ to 1.91 with a mean value of 0.66 for $\mathrm{Zn},-1.32$ to 0.04 with a mean value of -0.60 for $\mathrm{Cr},-0.47$ to 1.79 with a mean value of 0.7 for $\mathrm{Pb}$, -0.78 to 0.93 with a mean value of 0.18 for $\mathrm{Cu}$ and -1.78 to 1.8 with a mean value of -0.97 for $\mathrm{Ni}$. The mean values of $\mathrm{I}_{\text {geo }}$ increase in the order of $\mathrm{Ni}<\mathrm{Mn}<\mathrm{Cr}<\mathrm{Cu}<\mathrm{Zn}<\mathrm{Pb}$. The mean $\mathrm{I}_{\text {geo }}$ of $\mathrm{Cr}$, $\mathrm{Mn}$ and $\mathrm{Ni}$ less than 0 indicating that $\mathrm{Cr}, \mathrm{Mn}$ and $\mathrm{Ni}$ are unpolluted, the mean $\mathrm{I}_{\mathrm{geo}}$ of $\mathrm{Cu}, \mathrm{Pb}$ and $\mathrm{Zn}$ less than 1 indicating that $\mathrm{Cu}, \mathrm{Pb}$ and $\mathrm{Zn}$ are unpolluted to moderately polluted, nevertheless, $66.0 \% \mathrm{I}_{\text {geo }}$ of $\mathrm{Cu}, 79.2 \% \mathrm{I}_{\text {geo }}$ of $\mathrm{Pb}, 77.4 \% \mathrm{I}_{\text {geo }}$ of $\mathrm{Zn}$ and $1.9 \% \mathrm{I}_{\text {geo }}$ of $\mathrm{Cr}$ and $\mathrm{Ni}$, between 0 and 1 indicate unpolluted to moderately polluted, $18.9 \% \mathrm{I}_{\mathrm{geo}}$ of $\mathrm{Pb}, 13.2 \% \mathrm{I}_{\mathrm{geo}}$ of $\mathrm{Zn}$ and $1.9 \% \mathrm{I}_{\text {geo }}$ of Ni between 1 and 2 indicate moderately 
polluted.

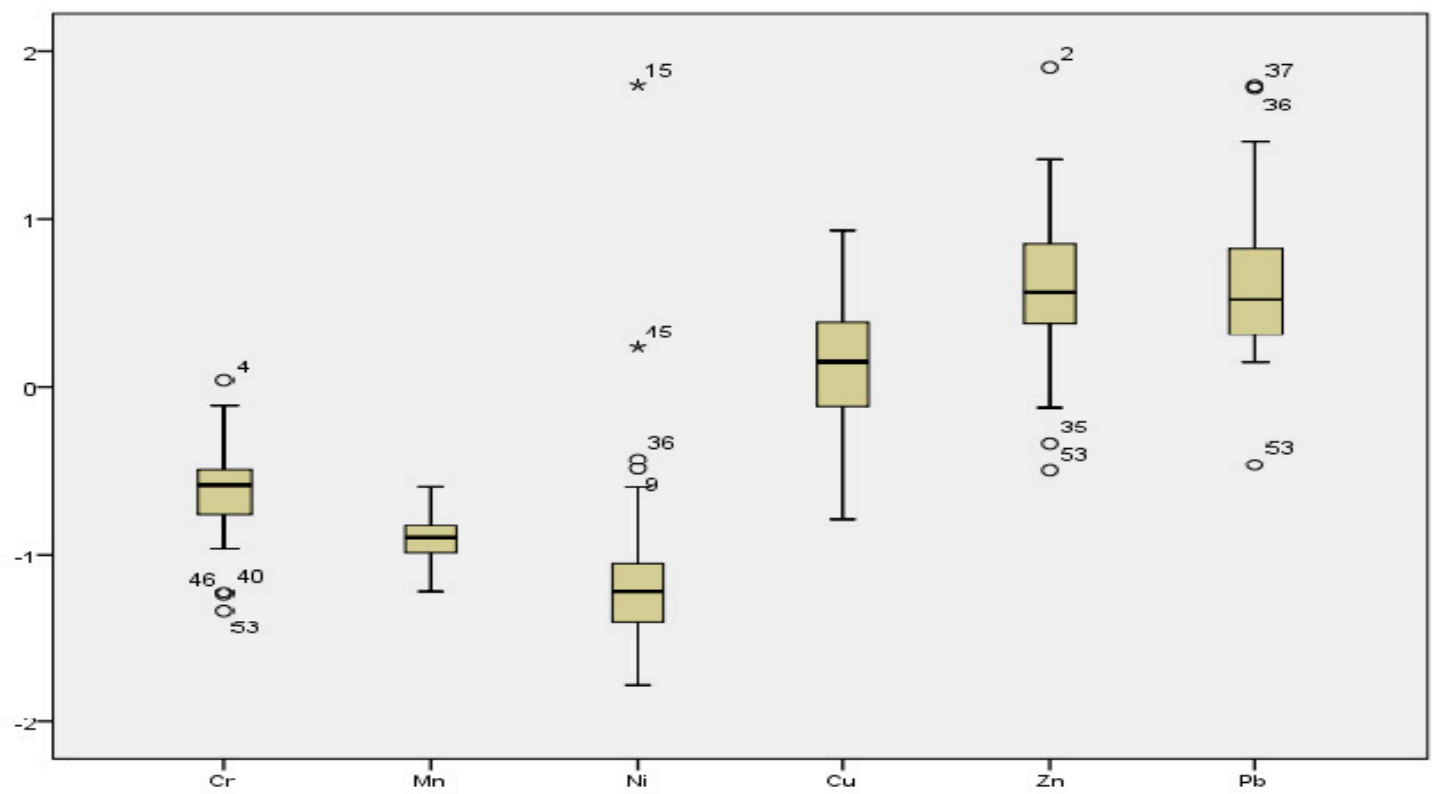

Fig. 1. Box-plot of $I_{g e o}$ for heavy metals in bus station dusts of Xifeng.

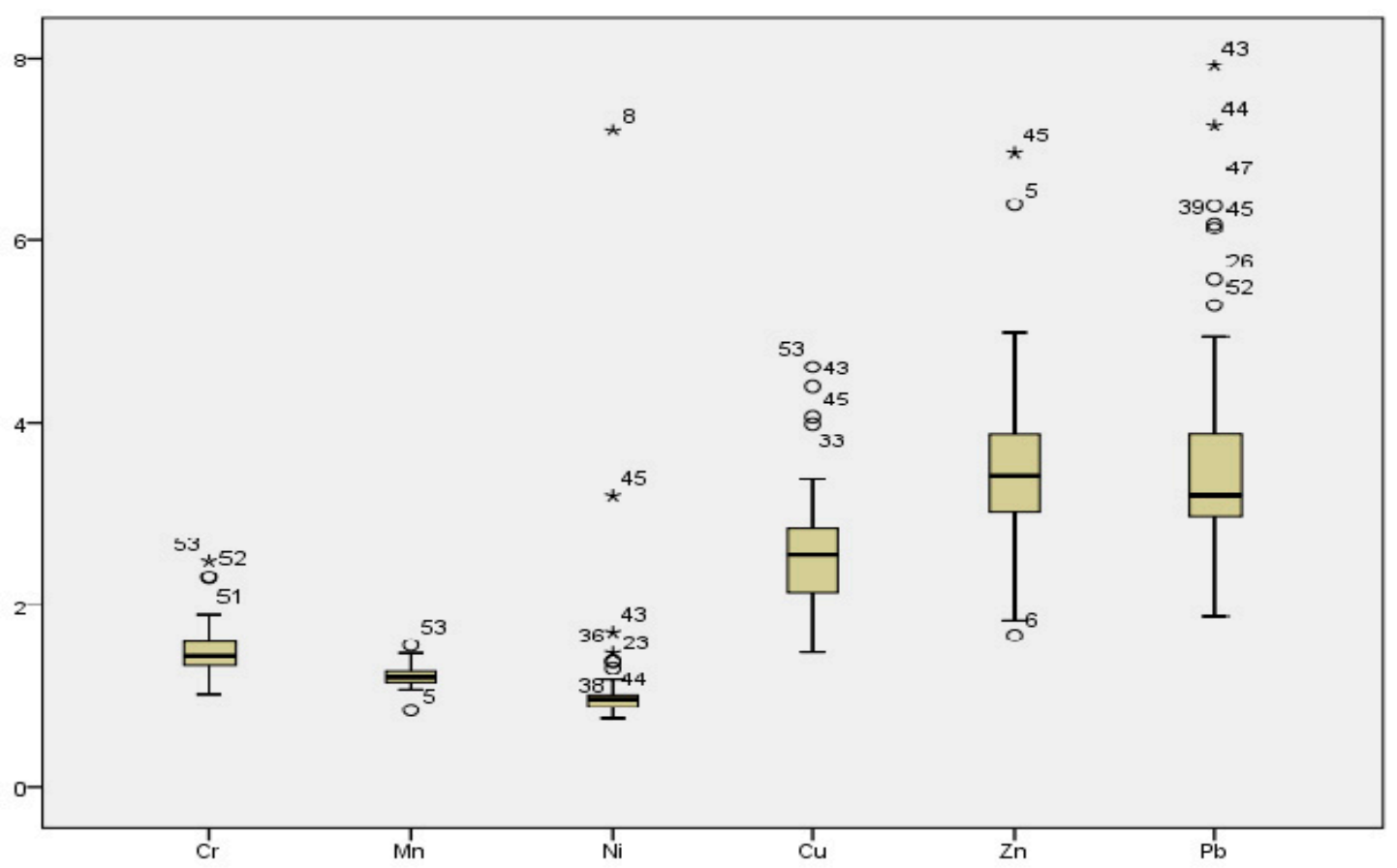

Fig. 2. Box-plot of EF for heavy metals in bus station dusts of Xifeng.

Enrichment factors of heavy metals were calculated for each bus station dusts sample relative to the background value of the elements in Chinese soil(CNEMC, 1990), choosing $\mathrm{Al}$ as the reference element. The $\mathrm{EF}$ of $\mathrm{Mn}, \mathrm{Zn}, \mathrm{Cr}, \mathrm{Pb}, \mathrm{Cu}$ and $\mathrm{Ni}$ is in the range of $0.847-1.558,1.667-6.961,1.023-2.485$, $1.873-7.915,1.482-4.611$ and $0.754-7.207$ with an average of 1.215, 3.549, 1.497, 3.618, 2.567 and 1.147, respectively (Fig. 2).

The mean $\mathrm{EF}$ of $\mathrm{Pb}, \mathrm{Cu}$ and $\mathrm{Zn}$ exceeds 2, while the mean $\mathrm{EF}$ of $\mathrm{Cr}, \mathrm{Mn}$ and $\mathrm{Ni}$ is lower than 2. maximum $\mathrm{EF}$ of $\mathrm{Ni}, \mathrm{Zn}$ and $\mathrm{Pb}$ are higher than 5 , which shows that $\mathrm{Ni}, \mathrm{Zn}$ and $\mathrm{Pb}$ in bus station dusts mainly originate from anthropogenic sources( Liu et al. 2003). It seems, as a consequence, that EF can 
also be an effective tool to distinguish a natural origin from anthropogenic sources in the study. The order of mean $\mathrm{EF}$ values is $\mathrm{Ni}<\mathrm{Mn}<\mathrm{Cr}<\mathrm{Cu}<\mathrm{Zn}<\mathrm{Pb}$, which can also be seen as the increasing order of their overall contamination degrees of bus station dusts in Xifeng. $\mathrm{EF}$ of $\mathrm{Ni}, \mathrm{Mn}$ and $\mathrm{Cr}$ have $96.2 \%$, $100 \%$ and $94.3 \%$ less than 2, respectively, revealing the lack of enrichment with $\mathrm{Ni}, \mathrm{Mn}$ and $\mathrm{Cr}$ as a whole, while only $1.9 \%$ and $5.7 \% \mathrm{EF}$ of $\mathrm{Ni}$ and $\mathrm{Cr}$ sample belongs to moderate enrichment. $\mathrm{EF}$ of $\mathrm{Cu}$, $\mathrm{Zn}$ and $\mathrm{Pb}$ have $83.0 \%, 92.4 \%$ and $84.9 \%$ in 2-5, respectively, indicates $\mathrm{Cu}, \mathrm{Zn}$ and $\mathrm{Pb}$ of bus station dusts are mainly moderate enrichment. while 3.8\% and 13.2\% EF of $\mathrm{Zn}$ and $\mathrm{Pb}$ sample more than 5, with mean EF 3.681 and 3.549, indicating significant enrichment. The analytical results of EF of heavy metals are same as the analytical results of $\mathrm{I}_{\mathrm{geo}}$.

The PIs, calculated according to the background concentration of heavy metals in Chinese soil, vary greatly across the different metals (Fig. 3). Ni and Mn exhibit lower values, ranging from 0.44 to 5.22 and from 0.64 to 0.99 , respectively. For Ni and Mn, the mean PI are 0.76 and 0.80 , only three samples Ni are classified as middle PI and one sample Ni is classified as high PI and all of the samples Mn have low-level PIs, indicating that the concentration of $\mathrm{Ni}$ and $\mathrm{Mn}$ in the bus station dusts samples are comparable with the background concentration of Chinese soil and there are low pollution of $\mathrm{Ni}$ and $\mathrm{Mn}$ in Xifeng bus station dusts samples. The mean PI for $\mathrm{Cu}, \mathrm{Zn}$ and $\mathrm{Pb}$ are 1.69, 2.36 and 2.40, and only one sample $\mathrm{Cu}$ is classified as low PI, and seven samples $\mathrm{Zn}$ and nine samples $\mathrm{Pb}$ are classified as high $\mathrm{PI}$, indicating middle to high $\mathrm{Cu}, \mathrm{Zn}$ and $\mathrm{Pb}$ pollution of bus station dusts in Xifeng.

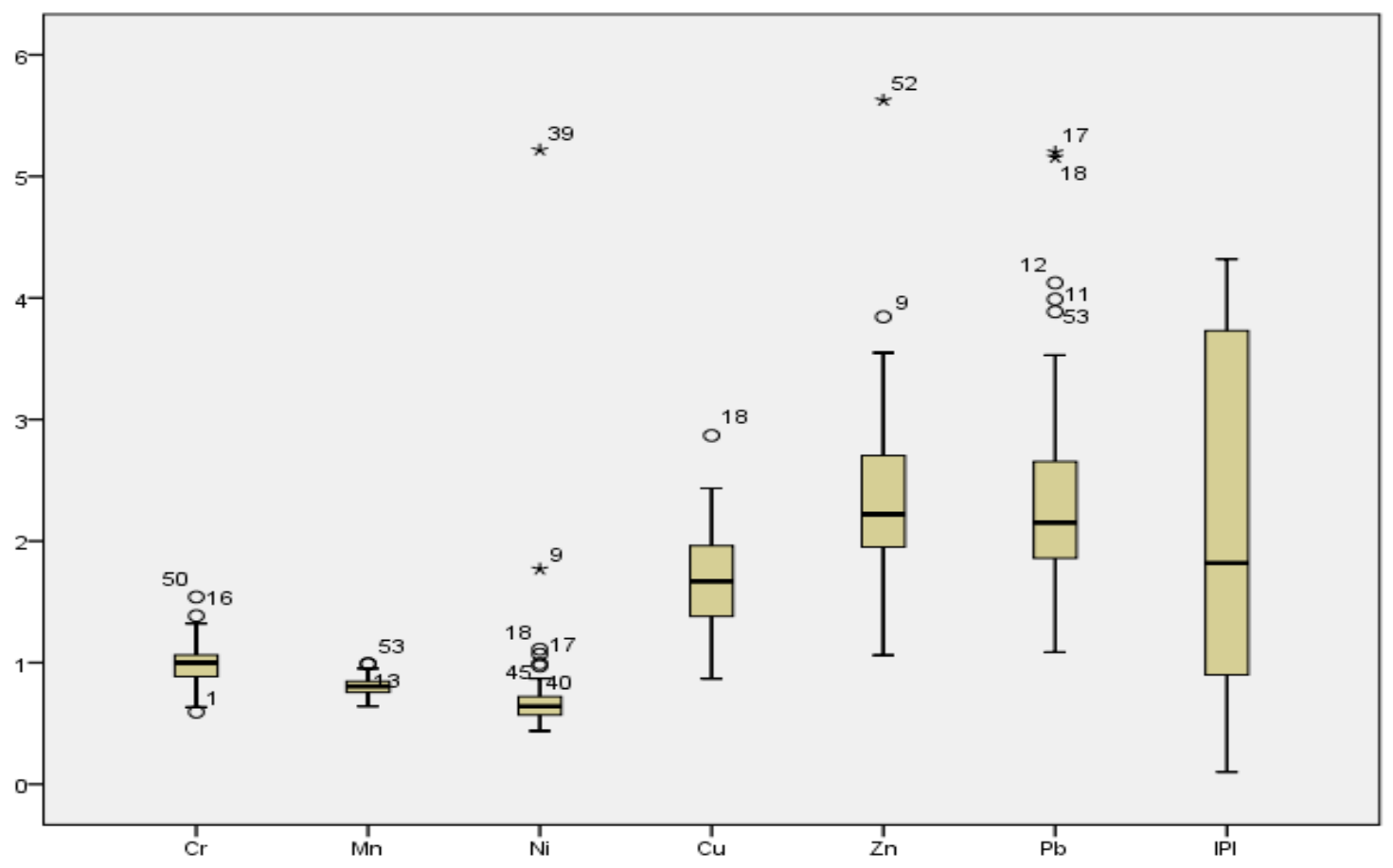

Fig. 3. Box-plot of PI and IPI for heavy metals in bus station dusts of Xifeng.

The PIs of $\mathrm{Cr}$ is middle since 26 samples are classified as low PI ( $\mathrm{PI} \leq 1)$ and 27 samples are classified as middle PI $(1<\mathrm{PI} \leq 3)$, ranging from 0.59 to 1.54 , with mean value of 0.99 for Cr. These data indicate that $\mathrm{Cr}$ of bus station dusts presented low to middle pollution in Xifeng. The IPI $\mathrm{I}_{\mathrm{s}}$ of bus station dusts samples vary from 0.10 to 4.32 with an average of 2.12 , indicating that all samples studied presented heavy metal high pollution. 
4. Conclusion

The concentrations of heavy metal $\mathrm{Ni}, \mathrm{Mn}, \mathrm{Cr}, \mathrm{Cu}, \mathrm{Zn}$ and $\mathrm{Pb}$ and their contamination level in bus station dusts collected from Xifeng, Northwest of China have been studied in the work. The concentration of $\mathrm{Mn}, \mathrm{Zn}, \mathrm{Cr}, \mathrm{Pb}, \mathrm{Cu}$ and $\mathrm{Ni}$ in bus station dusts ranges from 354.6 to 549.4, 64.7 to 343.2, 36.7 to $95.2,20.1$ to $96.2,17.8$ to 58.8 and 12.7 to $151.3 \mathrm{mg} \mathrm{kg}^{-1}$, with an arithmetic mean of $442.8,144.2,61.0,44.9,34.6$ and $22.2 \mathrm{mg} \mathrm{kg}^{-1}$, respectively. The concentrations of heavy metals investigated in the work are compared with the reported data of other cities streets dusts and with the background values of elements in Chinese soil. The results indicate that bus station dusts in Xifeng have elevated metal concentrations as a whole.

The calculated results of $I_{g e o}$ and EF of heavy metals reveal the order of $I_{\text {geo }}$ and EF are $\mathrm{Ni}<\mathrm{Mn}<\mathrm{Cr}<\mathrm{Cu}<\mathrm{Zn}<\mathrm{Pb}$. The high $\mathrm{I}_{\text {geo }}$ and $\mathrm{EF}$ for $\mathrm{Cu}, \mathrm{Zn}$ and $\mathrm{Pb}$ in bus station dusts indicate that there is a considerable $\mathrm{Cu}, \mathrm{Zn}$ and $\mathrm{Pb}$ pollution, which mainly originate from traffic and industry activities (such as oil refining and boiler emissions). The $\mathrm{I}_{\text {geo }}$ and $\mathrm{EF}$ of $\mathrm{Ni}, \mathrm{Mn}$ and $\mathrm{Cr}$ are low and the assessment results indicate an absence of distinct $\mathrm{Ni}, \mathrm{Mn}$ and $\mathrm{Cr}$ pollution in bus station dusts. The assessment results of $\mathrm{PI}$ also support $\mathrm{Cu}, \mathrm{Zn}$ and $\mathrm{Pb}$ in bus station dusts present middle pollution, and IPI indicates heavy metals of bus station dusts polluted highly. These findings indicate that more attention should be paid to heavy metal contamination of bus station dusts in Xifeng, especially $\mathrm{Pb}$.

Acknowledgments

The research was supported by the National Natural Science Foundation of China through Grant 41271510, the Fundamental Research Funds for the Central University GK201601009, the Longdong University PhD candidate scientific research fund LDXY151230. We thank Ma Ge, Yun Jiang, Yun Pujun et al. for their help with the experiments. Opinions in the paper do not constitute an endorsement or approval by the funding agencies and only reflect the personal views of the authors.

\section{References}

A.A. Odewande, A.F. Abimbola (2008) Contamination indices and heavy metal concentrations in urban soil of Ibadan metropolis, southwestern Nigeria, Environ. Geochem. Health 30:243-254.

A. Chatterjee, R.N. Banerjee (1999) Determination of lead and other metals in a residential area of greater Calcutta, Sci. Total Environ. 227:175-185.

A. Jiries, H.H. Hussein, Z. Halaseh (2001) The quality of water and sediments of street runoff in Amman, Jordan, Hydrol. Process. 15:815-824.

A.K. Upadhyay, K.K. Gupta, J.K. Sircar, M.K. Deb, G.L. Mundhara (2006) Heavy metals in freshly deposited sediments of river Subernarekha, India: an example of lithogenic and anthropogenic effects, Environ. Geol. 50:397-403.

A.K. Upadhyay, K.K. Gupta, J.K. Sircar, M.K. Deb, G.L. Mundhara (2007) Dominance of lithogenic effect for nickel, cobalt, chromium and mercury as found in freshly deposited sediments of the river Subernarekha, India, Environ. Geol. 51:1447-1453.

A.M.Gagneten, S.Gervasio, J.C.Paggi (2007) Heavy metal pollution and eutrophication in the lower Salado River Basin (Argentina), Water Air Soil Pollut. 178:335-349.

A.Mandal, D. Sengupta (2003) Radioelemental study of Kolaghat, thermal power plant, West Bengal, India: possible environmental hazards, Environ. Geol. 44:180-186.

A.Ordóñez, J. Loredo, E. deMiguel, S. Charlesworth (2003) Distribution of heavy metals in the bus station dusts and soils of an industrial district in Northern Spain, Arch. Environ. Contam. Toxicol. 44:160-170. 
A.Turner, L. Simmonds (2006) Elemental concentrations and metal bioaccessibility in UK household dust, Sci. Total Environ. 371:74-81.

Banerjee ADK (2003) Heavy metal levels and solid phase speciation in street dusts of Delhi, India. Environ Pollut 123:95-105.

Cao ZZ, Yang YH, Lu JL, Zhang CX (2011) Atmospheric particle characterization, distribution, and deposition in Xi'an, Shaanxi Province, Central China. Environ Pollut 159:577-584

Chen H, Lu XW, Chang YY, Xue WZ (2014) Heavy metal contamination in dust from kindergartens and elementary schools in Xi'an, China. Environ Earth Sci 71:2701-2709

Chen Ming, Lena Q., Hoogeweg C.G., and Harris W.G. (2001) Arsenic background concentrations in Florida, USA: Surface soils: determination and interpretation [J]. Environmental Forensics. 2:117-126.

CNEMC (China National Environmental Monitoring Centre) (1990) The background value of Chinese soil. Environmental Science Press of China, Beijing, 15-505 (in Chinese)

C. Bilos, J.C. Colombo, C.N. Skorupka, M.J. Rodriguez Presa,(2001) . Sources, distribution and variability of airborne trace metals in LaPlata District area, Argentina, Environ. Pollut. 11:149-158.

C. Gonzalez-Macias, I.Schifter, D.B.Lluch-Cota, L.Mendez-Rodriguez, S. Hernandez-Vazquez, (2007).

Environmental assessment of aromatic hydrocarbons - contaminated sediments of the Mexican Salina Cruz Bay, Environ. Monit. Assess. 133:187-207.

C. Gonzalez-Macias, I.Schifter, D.B.Lluch-Cota, L.Mendez-Rodriguez, S. Hernandez-Vazquez, (2006) . Distribution, enrichment and accumulation of heavy metals in coastal sediments of Salina Cruz Bay, Mexico, Environ. Monit. Assess. 118:211-230.

Duong TT, Lee BY (2011) Determining contamination level of heavy metals in road dust from busy traffic areas with different characteristics. J Environ Manage 92:554-562

D. Meza-Figueroa, M. De la O-Villanueva, M.L. De la Parra (2007) Heavy metal distribution in dust from elementary schools in Hermosillo, Sonora, México, Atmos. Environ. 41:276-288.

D. Varrica, G. Dongarrà, G. Sabatino, F. Monna (2003) Inorganic geochemistry of road-way dust from the metropolitan area of Palermo, Italy, Environ. Geol. 44:222-230.

E. Manno, D. Varrica, E. De Miguel, J.F. Llamas, E. Chacón, T. Berg, S. Larssen, O. Røyset, M. Vadset (1997) Origin and patterns of distribution of trace elements in bus station dusts: unleaded petrol and urban lead, Atmos. Environ. 31:2733-2740.

F. Ahmed, H. Ishiga (2006) Trace metal concentrations in bus station dusts of Dhaka district, Bangladesh, Atmos. Environ. 40:3835-3844.

Ferreira-Baptista L, De Miguel E (2005) Geochemistry and risk assessment of street dust in Luanda, Angola: a tropical urban environment. Atmos Environ 39:4501-4512

Fu Z, Zhai Y, Wang L, Zeng G, Li C, Peng W, Lan Y, Lu P (2012) Morphological, geochemical composition and origins of near-surface atmospheric dust in Changsha city of China. Environ Earth Sci 66:2207-2216

G. Jeelani, A.Q. Shah, Geochemical characteristics of water and sediment from the Dal Lake, G. Dongarrà (2006) Metal distribution in road dust samples collected in an urban area close to a petrochemical plant at Gela, Sicily, Atmos. Environ. 40:5929-5941.

G. Müller (1969) Index of geoaccumulation in sediments of the Rhine River, Geol. J. 2:108-118.

H. Arslan (2001) Heavy metals in bus station dusts in Bursa, Turkey, J. Trace Microprobe Tech. 19:439-445.

H. Yongming, D. Peixuan, C. Junji, E.S. Posmentier (2006) Multi variate analysis of heavy metal contamination in urban dusts of Xi'an, Central China, Sci. Total Environ. 355:176-186.

Han XF, Lu XW, Pang L, Ning XL (2014) Spatial distribution and ecological risk of heavy metal in street dust of Baotou city. Arid Land Geogr 37(3):561-569 (in Chinese)

Hu X, Zhang Y, Luo J, Wang TJ, Lian HZ, Ding ZH (2011) Bioaccessibility and health risk of arsenic, mercury and other metals in urban street dusts from a mega-city, Nanjing, China. Environ Pollut 


\section{9:1215-1221}

I. Staloki, J. Osan, R.E. Van Grieken, X-ray spectrometry, Anal. Chem. 76 (2004) 3445-3470.

J.E.Ferguson, N. Kim (1991) Trace elements in street and house dusts source and speciation, Sci. Total Environ. 100:125-150.

J.H. Lim, L.D. Sabin, K.C. Schiff, K.D. (2006) Stolzenbach, Concentration, size distribution, and dry deposition rate of particle-associated metals in the Los Angeles region, Atmos. Environ. 40:7810-7823.

Kashmir Himalaya (2006) constraints on weathering and anthropogenic activity, Environ. Geol. 50:12-23.

K. Loska, J. Cebula, J. Pelczar, D. Wiechula, J. Kwapulinski (1997) Use of enrichment, and contamination factors together with geoaccumulation indexes to evaluate the content of $\mathrm{Cd}, \mathrm{Pb}$, and $\mathrm{Ni}$ in the Rybnik water reservoir in Poland, Water Air Soil Pollut. 93:347-365.

L. Ferreira-Baptista, E. De Miguel, Geochemistry and risk assessment of bus station dusts in Luanda, Angola: a tropical urban environment, Atmos. Environ. 39 (2005) 4501-4512.

Li C, Li FY, Zhang Y, Liu TW, Hou W. Spatial distribution characteristics of heavy metals in street dust in Shenyang city. Ecology Environ 2008;17:560-4.

Li KX, Liang T, Wang LQ (2015) Risk assessment of atmospheric heavy metals exposure in Baotou, a typical industrial city in northern China. Environ Geochem Health. doi:10.1007/s10653-

015-9765-1

LI Kexin, LIANG Tao, WANG Lingqing, YANG Zhiping (2015). Contamination and health risk assessment of heavy metals in road dust in Bayan Obo Mining Region in Inner Mongolia, North China.J. Geogr. Sci. 25(12):1439-1451

LI Xiaoyan, CAO Yijin, QI Le, and SHU Fu (2012). The distribution characteristics of heavy metals in Guiyang urban soils.Chin.J.Geochem. 31:174-180

Lu XW, Wang LJ, Lei K, Huang J, Zhai Y (2009a) Contamination assessment of copper, lead, zinc, manganese and nickel in street dust of Baoji, NW China. J Hazard Mater 161:1058-1062

Lu XW, Wang LJ, Li LY, Lei K, Huang L, Kang D (2010) Multivariate statistical analysis of heavy metals in street dust of Baoji, NW China. J Hazard Mater 173:744-749

Lu XW, Wu X, Wang YW, Chen H, Gao PP, Fu Y (2014a) Risk assessment of toxic metals in street dust from a medium-sized industrial city of China. Ecotoxicol Environ Saf 106:154-163

Lu XW, Zhang XL, Li LY, Chen H (2014b) Assessment of metals pollution and health risk in dust from nursery schools in Xi'an, China. Environ Res 128:27-34

Lu XW, Loretta YL, Wang LJ, Lei K, Huang J, Zhai YX (2009b) Contamination assessment of mercury and arsenic in roadway dust from Baoji, China. Atmos Environ 43:2489-2496

Ma J, Singhirunnusorn W (2012) Distribution and health risk assessment of heavy metals in surface dusts of Maha Sarakham Municipality. Proc-Soc Behav Sci 50:280-293

M. Tüzen (2003) Determination of heavy metals in soil, mushroom and plant samples by atomic absorption spectrometry, Microchem. J. 74:289-297.

M. Imperato, P. Adamo, D. Naimo, M. Arienzo, D. Stanzione, P. Violante (2003) Spatial distribution of heavy metals in urban soils of Naples district (Italy), Environ. Pollut. 124:247-256.

M.J. dos Anjos, R.T. Lopes, E.F.O. De Jesus, J.T. Assis, R. Cesareo, C.A.A. Barradas (2000) Quantitative analysis of metals in soil using X-ray fluorescence, Spectrochim. Acta B 55:1189-1194.

M.S. Akhter, I.M. Madany (1993) Heavy metals in bus station dusts and house dust in Bahrain, Water Air Soil Pollut. 66:111-119.

Moreno T, Karanasiou A, Amato F et al. (2013) Daily and hourly sourcing of metallic and mineral dust in urban air contaminated by traffic and coal-burning emissions. Atmospheric Environment, 68:33-44.

N. Hu, Z.Li, P.Huang, C.Tao (2006) Distribution and mobility of metals in agricultural soils nearacoppersmelterin South China, Environ. Geochem. Health. 28:19-26. 
N.S. Duzgoren-Aydin (2007) Sources and characteristics of lead pollution in the urban environment of Guangzhou, Sci. Total Environ. 385:182-195.

N.S. Duzgoren-Aydin, C.S.C. Wong, A. Aydin, Z. Song, M. You, X.D. Li (2006) Heavy metal contamination and distribution in the urban environment of Guangzhou, SE China, Environ. Geochem. Health 28:375-391.

N. Sezgin, H.K. Ozcan, G. Demir, S. Nemlioglu, C. Bayat (2003) Determination of heavy metal concentrations in bus station dusts in Istanbul E-5 highway, Environ. Int. 29:979-985.

O.A. Al-Khashman (2004) Heavy metal distribution in dust, bus station dusts and soils from the work place in Karak Industrial Estate, Jordan, Atmos. Environ. 38:6803-6812.

O.A. Al-Khashman (2007) Determination of metal accumulation in deposited bus station dusts in Amman, Jordan, Environ. Geochem. Health 29:1-10.

O.A. Al-Khashman (2007) The investigation of metal concentrations in bus station dusts samples in Aqaba district, Jordan, Environ. Geochem. Health 29:197-207.

P.E. Rasmussen, K.S. Subramanian, B.J. Jessiman (2001) A multi-element profile of house dust in relation to exterior dust and soils in the district of Ottawa, Canada, Sci. Total Environ. 267:125-140.

Q.T.Liu, M.E.Diamond, S.E.Gingrich, J.M.Ondov, P. Maciejczyk, G.A. Sterm (2003) Accumu

-lation of metals, trace elements and semivolatile organic compounds on exterior windows surfaces in Baltimore, Environ. Pollut. 122:51-61.

Shi GT, Chen ZL, Xu SY, Zhang J, Wang L, Bi CJ, Teng JY (2008) Potentially toxic metal contamination of urban soils and roadside dust in Shanghai, China. Environ Pollut 156:251-260

Shi GT, Chen ZL, Bi CJ, Wang L, Teng JY, Li YS, Xu SY (2011) A comparative study of health risk of potentially toxic metals in urban and suburban road dust in the most populated city of China. Atmos Environ 45:764-771

Shi XM, Wang JH (2013) Comparison of different methods for assessing heavy metal contamination in street dust of Xianyang city, NW China. Environ Earth Sci 68:2409-2415

S. Azimi, V. Rocher, M. Muller, R. Moilleron, D.R. Thevenot (2005) Sources, distribution and variability of hydrocarbons and metals in atmospheric deposition in an urban area (Paris, France), Sci. Total Environ. 337:223-239.

S. Charlesworth, M. Everett, R. McCarthy, A.Ordóñez, E.de Miguel (2003) A comparative study of heavy metal concentration and distribution in deposited bus station dusts in a large and a small urban area:Birmingham and Coventry, West Mid-lands, UK, Environ. Int. 29:563-573.

Ş. Kartal, Z. Aydın, S. Tokalıóglu (2006) Fractionation of metals in street sediment samples by using the BCR sequential extraction procedure and multivariate statistical elucidation of the data, J. Hazard. Mater. 132:80-89.

Ş. Tokalıóglu, Ş. Kartal (2006) Multivariate analysis of the data and speciation of heavy metals in bus station dusts samples from the organized industrial district in Kayseri (Turkey), Atmos. Environ. 40:2797-2805.

T.B. Chen, Y.M. Zheng, M. Lei, Z.C. Huang, H.T. Wu, H. Chen, K.K. Fan, K. Yu, X. Wu, Q.Z. Tian (2005) Assessment of heavy metal pollution in surface soils of urban parks in Beijing, China, Chemosphere 60:542-551.

U.Gemici, G.Tarcan (2007) Assessment of the pollutants in farming soils and waters around untreated abandoned Türkönü mercury mine (Turkey), Bull. Environ. Contam. Toxicol. 79:20-24.

Wang L, Liang T, Zhang Q et al.2014. Rare earth element components in atmospheric particulates in the Bayan Obo mine region. Environmental Research, 131:64-70.

Wang LJ, Lu XW, Li LY, Ren CH, Luo DC, Chen JH (2015) Content, speciation and pollution assessment of $\mathrm{Cu}, \mathrm{Pb}$ and $\mathrm{Zn}$ in soil around the lead-zinc smelting plant of Baoji, NW China. Environ Earth Sci 73:5281-5288

Wang LQ, Liang T (2014) Accumulation and fractionation of rare earth elements in atmospheric particulates 
around a mine tailing in Baotou, China. Atmos Environ 88:23-29

Wei BG, Yang LS (2010) A review of heavy metal contaminations in urban soils, urban road dusts and agricultural soils from China. Microchem J 94:99-107

X. Li, C.S. Poon, P.S. Liu (2001) Heavy metal contamination of urban soils and bus station dusts in Hong Kong, Appl. Geochem. 16:1361-1368.

X. Li, C.Huang (2007) Environmentimpactofheavymetalsonurbansoilinthevicinity of industrial area of Xifeng district, P.R. China, Environ. Geol. 52:1631-1637.

Xiufeng Han, Xinwei Lu, Qinghui Zhang, Wuyuntana, Quansheng Hai, Huiyun Pan (2016). Grain-size distribution and contamination characteristics of heavy metal in street dust of Baotou, China. Environ Earth Sci: $75: 468$

Xu X, Lu XW, Han XF, Zhao N (2015) Ecological and health risk assessment of metal in resuspended particles of urban street dust from an industrial city in China. Curr Sci 108:72-79

Y.Tasdemir, C.Kural (2005) Atmospheric dry deposition fluxes of trace elements measured in Bursa, Turkey, Environ. Pollut. 138:462-472.

Y. Hao, Z. Guo, Z. Yang, M. Fang, J. Feng (2007) Seasonal variations and sources of various elements in the atmospheric aerosols in Qingdao, China, Atmos. Res. 85:27-37.

Z.L.L. Yeung, R.C.W. Kwok, K.N. Yu (2003) Determination of multi-element profiles of bus station dusts using energy dispersive X-ray fluorescence (EDXRF), Appl. Radiat. Isot. 58:339-346.

Zhao HT, Li XY (2013) Risk assessment of metals in road-deposited sediment along an urban-rural gradient. Environ Pollut 174:297-304

Zhao N, Lu XW, Chao SG (2014) Level and contamination assessment of environmentally sensitive elements in smaller than 100 um street dust particles from Xining, China. Int J Environ Res Publ Health 11:2536-2549 Zheng, N., Liu, J., Wang, Q., \& Liang, Z. (2010). Health risk assessment of heavy metal exposure to street dust in the zinc smelting district, Northeast of China. Science of the Total Environment, 408(4):726-733.

(C) 2016 by the authors; licensee Preprints, Basel, Switzerland. This article is an open access article distributed under the terms and conditions of the Creative Commons by Attribution (CC-BY) license (http://creativecommons.org/licenses/by/4.0/). 